\title{
Tillage Practices Usage in Early Warning Prediction of Atrazine Pollution
}

\author{
J. E. Quansah, B. A. Engel, I. Chaubey
}

\begin{abstract}
Tillage and pesticide management are important factors controlling pesticide losses from agricultural watersheds. In this research, tillage activities were mapped from Landsat TM and MODIS data and were used in Soil and Water Assessment Tool (SWAT) model to simulate atrazine concentrations in the St. Joseph River in northeastern Indiana. The calibrated and validated model proved to be crucial in making early warning predictions and decisions on atrazine pollution. Average NashSutcliffe efficiency (NSE) values of 0.56 and 0.70 were obtained for daily and monthly stream flow calibration, respectively, while those for validation were 0.55 and 0.79 , respectively. The best NSE values ranged from 0.06 to 0.42 for daily atrazine calibrations at four locations within the watershed and from 0.01 to 0.29 during validation. Daily and monthly $R^{2}$ values at the St. Joseph watershed outlet during the atrazine validation were 0.35 and 0.63 , respectively. Although NSE values for some water quality stations were poor, predicted atrazine concentrations compared reasonably well to measured trends at the watershed outlet. Pollution peaks in simulated atrazine concentrations were also within days of measured atrazine concentrations. The research showed that the temporal and spatial trend of tillage activities, which influences the timing and location of atrazine applications, together with application amounts have significant impact on critical areas and concentration levels of atrazine pollution. Uncertainties in observed data could also affect the model outcome. The results showed the potential application in early warning prediction of atrazine pollution and can be used to make appropriate management decisions to mitigate this problem.
\end{abstract}

Keywords. Atrazine, Early warning prediction, St. Joseph watershed, SWAT, Tillage practices, Water quality.

A gricultural management can sometimes have negative impacts on the environment and result in increased instances of agricultural nonpointsource pollution and soil erosion. Tillage practices as well as chemical application rates, methods, and timing with respect to rainfall events are some of the factors that influence the proportion of agricultural chemicals that are washed off into receiving ground and surface water systems (Gorneau et al., 2001).The environmental damage, economic, and health impacts of polluted surface and groundwater resources can be very large, and the use or restoration of such polluted water is expensive.

Research efforts continue to be invested in identifying best management practices (BMPs) that control pollutant losses (Gitau et al., 2004) while maximizing crop yield. To assess the potential level of agricultural chemical pollution with respect to surface water quality, field studies aimed at data collection are often done using onsite platforms of contamination monitoring and sampling systems (EPA, 2005). However, this approach is expensive, labor-intensive,

Submitted for review in January 2008 as manuscript number SW 7376; approved for publication by the Soil \& Water Division of ASABE in June 2008.

The authors are Joseph E. Quansah, ASABE Member Engineer, Post-Doctoral Research Associate, Bernard A. Engel, ASABE Member Engineer, Professor and Head, and Indrajeet Chaubey, ASABE Member Engineer, Associate Professor, Department of Agricultural and Biological Engineering and Department of Earth and Atmospheric Sciences, Purdue University, West Lafayette, Indiana. Corresponding author: Bernard A. Engel, Purdue University, ABE Bldg., 225 S. University St., West Lafayette, IN; phone: 765-588-1197; fax: 765-496-1115; e-mail: engelb@purdue. edu. and spatially limited in coverage and network density, reducing the chances of adequate sampling for the detection of most pollutants in streams and water bodies.

To complement water quality data, mathematical models are used to simulate likely land, hydrologic, and climatic processes over larger watersheds utilizing field data. Modeling helps in the identification of pollution sources, critical areas, and timing during evaluation of environmental degradation and early warning prediction of point- and nonpoint-source pollution (Quansah, 2007). Some of these models include the Water Erosion Prediction Project (WEPP) model for simulating soil loss from erosion (Laflen et al., 1991), Soil and Water Assessment Tool (SWAT) for predicting sediment and agricultural chemical yields in large, complex watersheds (Arnold et al., 1998), Agricultural Drainage and Pesticide Transport (ADAPT) model for determining agricultural migration into groundwater (Chung et al., 1992), National Agricultural Pesticide Risk Analysis (NAPRA) and Groundwater Loading Effects of Agricultural Management Systems (GLEAMS) for assessing risk of pesticide loss to ground and surface water (Adeuya et al., 2005), and other models for predicting evapotranspiration and carbon sequestration (Gowda et al., 2005).

Atrazine (2-chloro-4-ethylamino-6-isopropylanminos-triazine) is one of the most effective, least expensive, and heavily used pesticides in the Corn Belt region of the U.S. Atrazine is a colorless, crystalline solid organic compound with water solubility of $33 \mathrm{mg} \mathrm{L}^{-1}$ at $25^{\circ} \mathrm{C}$ that also adsorbs to clay-rich or organic matter rich soils and has a six-month half-life in water (WHO, 1996). In Indiana, it is applied on approximately $86 \%$ of corn fields at an average application

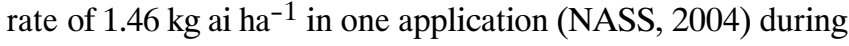


the April and May planting season. The application timing often coincides with the heavy spring rains that saturate the soil and result in potentially up to $18 \%$ of applied atrazine (Huber, 1993) being transported from application fields into nearby streams and reservoirs (Johnson et al., 2004), resulting in widespread contamination in the region.

Atrazine can be harmful to human and animal health when consumed long-term at concentration levels above the EPA's drinking water standard or maximum contaminant level (MCL) of $3 \mathrm{ppb}$. During an EPA ecological watershed monitoring program (2004-2006), all eleven monitored watersheds in Indiana showed atrazine concentrations above $3 \mathrm{ppb}$ MCL, with averages concentration levels ranging from 0.71 to $7.5 \mathrm{ppb}$ and maximum levels ranging from 8.6 to $237.5 \mathrm{ppb}$ (EPA, 2007). In Indiana, atrazine has been found in $47 \%$ of finished water samples from Indiana public water systems participating in the Federal Safe Drinking Water Act (Johnson et al., 2004). Atrazine reaction with chlorine during the treatment of polluted surface water for drinking can also produce detrimental byproducts (Ybarra et al., 2004). Plant managers therefore need adequate time and information on atrazine concentrations in their source water to help them adjust water treatment procedures to neutralize atrazine concentrations. There is, thus, the need for early warning prediction of likely critical pollution areas and concentrations of atrazine in such surface water systems so that efficient water management and water quality protection measures can be taken (Quansah, 2007).

In SWAT modeling research by Vazquez-Amabile et al. (2006) to simulate atrazine concentrations in the St. Joseph watershed in northeastern Indiana, atrazine application was made as a function of percentage crop planted using USDA National Agricultural Statistics Service (NASS) crop progress reports. A multiple application ratio was then generically applied to all hydrologic response units (HRUs). This is similar to research done by Neitsch et al. (2002b) to simulate pesticide concentrations in Sugar Creek. VazquezAmabile et al. (2006), however, concluded that tillage timing and pesticide application dates and rates were a source of significant uncertainty in the model.

The goal of this research was to further the ability to model atrazine concentrations in runoff, by combining remote sensing monitoring of tillage activities, which typically precede planting and pesticide application, and integrating this information with SWAT modeling to simulate the impact of such management activities on atrazine pollution. In this effort, the model results were analyzed to identify the potential of utilizing them as an early warning information source for atrazine pollution. The analysis was tested on the St. Joseph watershed in northeastern Indiana.

\section{Materials ANd Methods}

\section{SoIl AND WATER ASSESSMent ToOl (SWAT)}

SWAT is a physically based, distributed parameter, continuous simulation hydrological model used for quantifying the impact of land management practices on water, sediment, and agricultural chemical yields in large, complex watersheds with varying soils, land use, and management conditions over long periods of time (Arnold et al., 1998). The different SWAT model components describe processes associated with water movement, sediment movement, soils, temperature, weather, plant growth, nutrients, pesticides, and land management (Neitsch et al., 2002a). In each spatial subunit, water balance is represented by several storage volumes (e.g., canopy storage, snow, soil profile, shallow aquifer, and deep aquifer). Soil water processes include infiltration, evaporation, plant uptake, lateral flow, and percolation to deeper layers. SWAT incorporates routing and in-stream pesticide transformations, as well as reservoir transformations into the model (Neitsch et al., 2002a).

SWAT divides a watershed into a number of subbasins based on the drainage area of tributaries. Each subbasin is further divided into a number of spatially uniform HRUs based on land use, soil type, and topography. The hydrologic analysis is computed at the HRU level and extended over the whole watershed. The GIS-based capabilities allow for the spatial relation of hydrological and precipitation data in computing runoff and agricultural chemical transportation as related to specific management practices within any HRU, while providing a visual interpretation and analysis of results.

SWAT model simulations were developed for the St. Joseph watershed using various input variables described below. The model was calibrated and validated for hydrology and atrazine concentrations, and the results from the simulations were used in statistical analyses in evaluating the performance of the model as a tool for potential early warning predicting of atrazine pollution.

\section{Study Area}

The research area is the St. Joseph watershed (8-digit HUC 04100003), with about $56 \%$ of the watershed in northeastern Indiana and $22 \%$ each in northwestern Ohio and southeastern Michigan (fig. 1). The total watershed area is about $2821 \mathrm{~km}^{2}$, with agricultural croplands as the major land use covering approximately $76 \%$ of the area, $95 \%$ of which is under corn and soybean cultivation. Other land uses are forest lands, wetlands, residential, urban, transportation, and water. The agricultural management system has high conventional tillage activities and heavy chemical use, resulting in widespread contamination within the watershed. Soils in the headwaters portion of the watershed are very deep, well drained, sandy loams and loamy sand on outwash plains. The middle portion of the watershed has very deep, well drained to somewhat poorly drained loamy soils on moraines, and lower portions are deep to somewhat deep, very poorly drained, clayey and loamy soils on outwash plains and ground moraines (SJRWI, 2006). Average annual precipitation in the watershed is approximately $900 \mathrm{~mm}$, and the average temperature during crop growth seasons ranges from $10^{\circ} \mathrm{C}$ to $23^{\circ} \mathrm{C}$. The main St. Joseph River runs about 100 $\mathrm{km}$ between Osseo, Michigan, and Fort Wayne, Indiana, and serves as the main source of drinking water for approximately 200,000 residents of Fort Wayne (SJRWI, 2006).

\section{SWAT INPUT DATASETS}

The National Elevation Dataset (NED) was used to delineate the watershed and subbasins, while the National Land Cover Database 2001 (NLCD 2001) was used to develop land use information for the model. The USDA Natural Resources Conservation Service (NRCS) State Soil Geographic Database (STATSGO) was used as soil input 


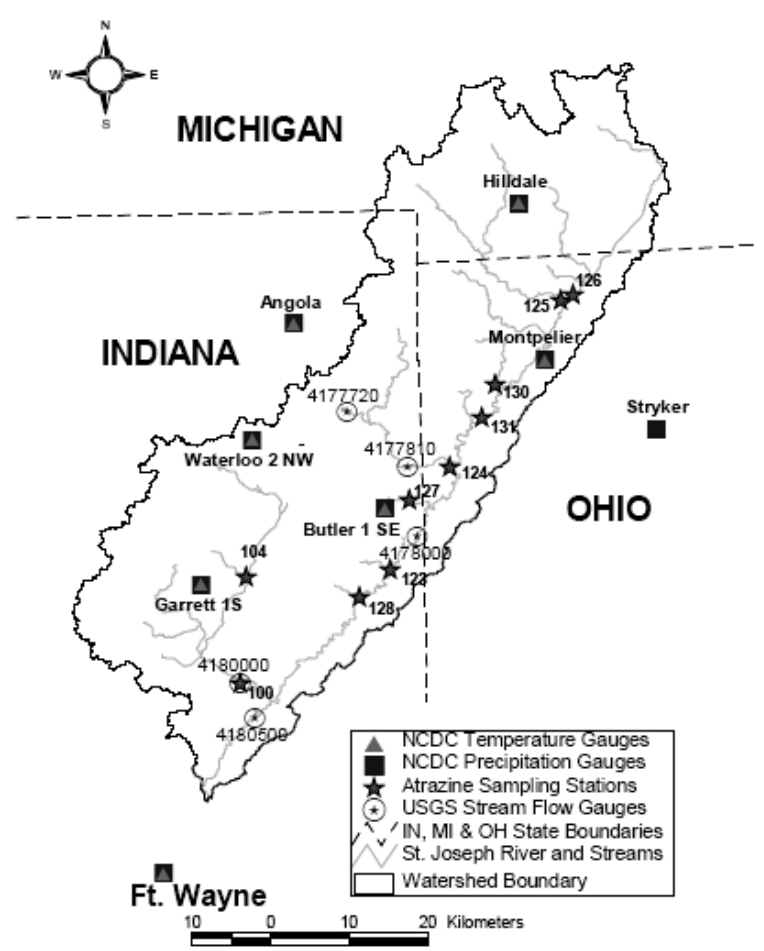

Figure 1. Location of the St. Joseph watershed showing weather stations, USGS gauges, and water quality sampling stations.

layer. Major classification of the soils, according to soil properties with similar runoff potential and infiltration rate under similar storm and cover conditions, were hydrologic groups A, B, and C, and had seventeen STATSGO map unit identifiers (MUIDs). Tillage layers for years 2000 to 2004 were obtained by mapping tillage practices from MODIS and Landsat 5 TM satellite data, using logistic regression models (Quansah, 2007).

Precipitation and temperature data (fig. 1) for eight active gauge stations within and around the watershed were downloaded from the National Oceanic and Atmospheric Administration's (NOAA) National Climatic Data Centers (NCDC) website, while stream flow data for five USGS gauge stations (fig. 1) were obtained from the USGS website. Observed water quality data from ten atrazine sampling stations (fig. 1), between 1996 and 2004, were obtained from the St. Joseph River Watershed Initiative (SJRWI), for the model calibration and validation. Additional measured atrazine data (2000-2004) for the watershed outlet were obtained from the Three Rivers Filtration Plant at Fort Wayne, Indiana. Figure 1 shows the location of the St. Joseph watershed, and locations of USGS gauges, NCDC weather stations, and SJRWI grab sample stations within the watershed.

\section{SWAT SETUP}

Since NLCD land use has no categorized agricultural land uses, the agricultural areas were partitioned into different crop areas according to average Indiana NASS crop distribution using the splitting tool in the SWAT land use reclass option (Di Luzio et al., 2002). The new NLCD agricultural area land uses were $49 \%$ soybean, $46 \%$ corn, $3 \%$ alfalfa, and $2 \%$ winter wheat. SWAT automatically redistributes the different crop areas over the various subbasins according to their sizes during the land use and soil setup. To control the number of HRUs, the multiple HRUs land use/ soils option with a $5 \% / 5 \%$ threshold, respectively, was used in computing the HRU distribution.

Corn and soybean rotation during the planting season (late April to late May) was based on predominant crop rotation mapped from 2000 to 2004 NASS crop maps for northeastern Indiana, using the ArcGIS Spatial Analyst tool. The major rotations identified and used in the SWAT management files (crop rotation scenarios) were corn-soybean/soybean-corn rotations.

SWAT agricultural management files were based on spatial and temporal tillage practices mapped from MODIS and Landsat $5 \mathrm{TM}$ data as well as other prevailing management practices in the watershed. Tillage operations used were conventional tillage for which $85 \%$ of crop residues were incorporated into the soil, through moldboard or chisel plowing and disking (Titi, 2003), conservation tillage for which at least $30 \%$ of the previous year's crop residue remained on the soil surface after planting (CTIC, 1998), and no-till practices where top soils were left undisturbed prior to planting and the majority of the crop residue remained after planting (CTIC, 1998).

Incorporating five years of tillage data into the SWAT model resulted in the creation of 5-year crop rotation scenarios. Since, HRUs are not spatially continuous, the watershed was divided into 56 subbasins, with an average size of $50 \mathrm{~km}^{2}$, to allow all HRUs in a particular subbasin to be assigned the same identified tillage type and tillage date within that subbasin (fig. 2a). Identifying tillage type and dates for each subbasin involved overlaying the subbasin layer with single-layered (fig. 2b) and multi-layered (fig. 2c) tillage maps and systematically identifying the majority tillage type and dates for each subbasin and HRU. The tillage maps provided two main information sources for developing agricultural management files used in the SWAT model: timing and spatial distribution of tillage, and timing of planting and pesticide applications.

\section{Tillage Timing and Spatial Distribution}

The timing of the satellite images provided an approximate timing of the tillage processes. Because MODIS and Landsat have different temporal frequencies, different approaches were used in analyzing their tillage products with respect to tillage timing. Since MODIS has a temporal frequency of a day, it was estimated that identified tillage could possibly be within the last 2 days of the image acquisition date (Quansah, 2007). On the other hand, Landsat TM has a temporal resolution of 16 days, and this would indicate that any identified tillage could be within the last two weeks before the date of the imagery. A mid-length of one week (7 days) to date of acquisition was estimated for Landsat TM tillage products (Quansah, 2007). Tillage types for the different subbasins were based on the spatial distribution of tillage practices.

\section{Timing of Planting and Pesticide Applications}

After determining the timing of the tillage processes, other agricultural management activities were derived from this information. Planting was scheduled one week (7 days) after tillage had occurred, and atrazine was applied 3 days after planting and 10 days after tillage activity. The 10-day atrazine application lag time closely matched the NASS corn planting progress report. A 3-day lag time was explored but resulted in atrazine concentrations peaks occurring too early 


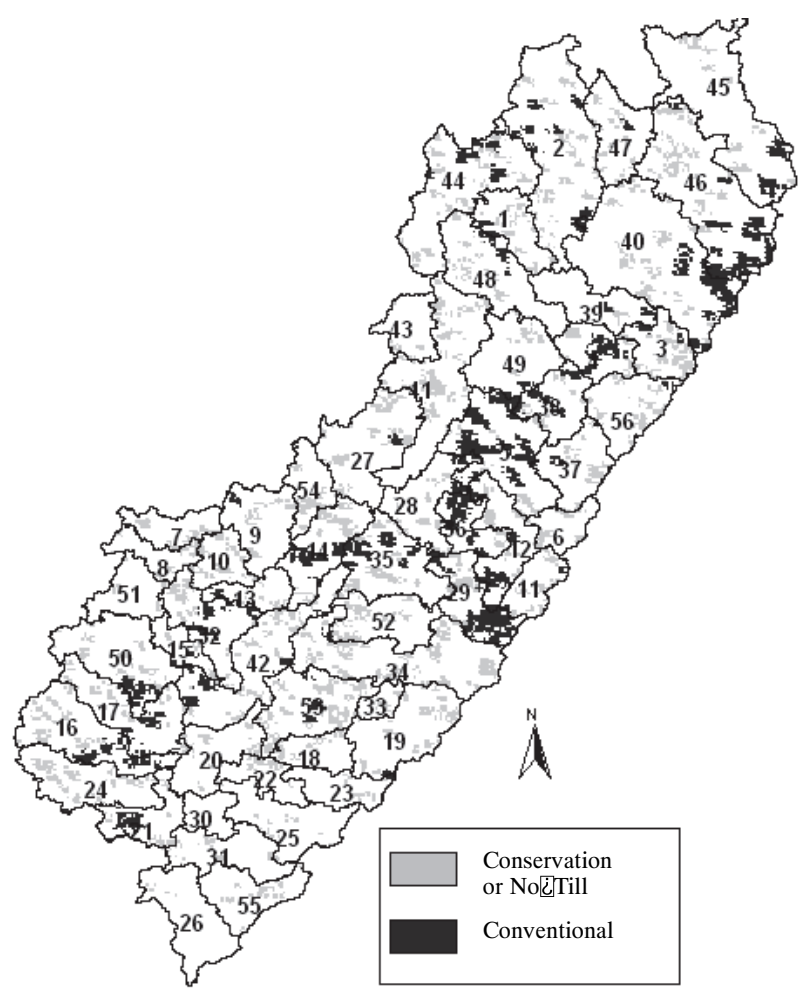

(a)

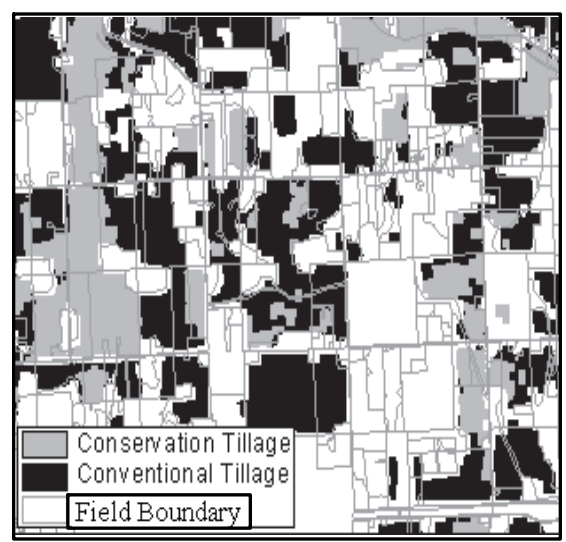

(b)

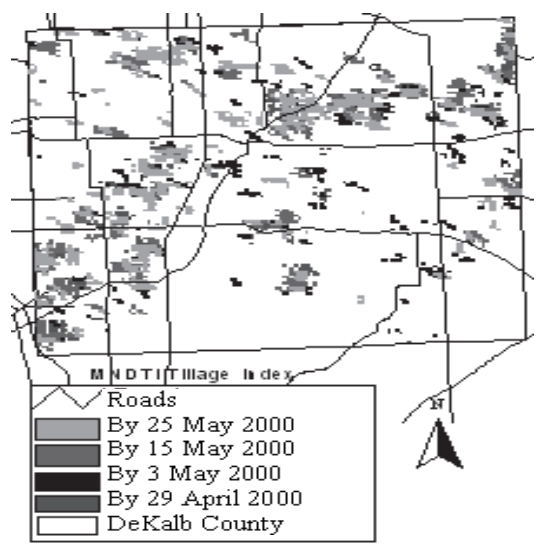

(c)

Figure 2. (a) MODIS tillage for 29 April 2000 overlaid with subbasin layer, (b) Landsat-derived tillage map for 13 May 2000, and (c) MODIS-derived multi-layered conventional tillage map for 2000.

in comparison to the measured data (Quansah, 2007). Application of atrazine was done in single applications for all years at average application rates $(1.50,1.50,1.41,1.44$. and $1.46 \mathrm{~kg} \mathrm{ai} \mathrm{ha}^{-1}$, respectively) based on yearly averages from 1996 to 2000, as reported by NASS (2004) for northeastern Indiana.

The tillage practices and atrazine application rates helped in mimicking spatial progress and changes in crop planting and atrazine application during the planting season. However, due to lack of satellite data for some tillage times or excessive clouds, the tillage status of certain areas could not be identified as frequently as desired. To estimate the atrazine application dates for such cases, NASS crop planting progress reports (NASS, 2004) were used to determine the application estimates and trends for such areas. In addition, since NASS (2004) reported that average atrazine use in Indiana was on $86 \%$ of corn, atrazine was applied randomly to $86 \%$ of corn subbasins in the watershed.

During the SWAT setup, the no-till option was selected for no-till/conservation tillage areas, and a field cultivator option was selected for conventional tillage, since planting was assumed to occur a week after tillage was estimated (Atwood et al., 2000). Table 1 provides a tabulation of tillage progress with time as related to different subbasins and atrazine applications. The table also shows the NASS corn planting progress report. The final pesticide application dates

Table 1. Distribution of atrazine within subbasins as related to tillage progress for year 1 of 5-year rotation.

\begin{tabular}{|c|c|c|c|c|c|c|}
\hline \multirow{2}{*}{$\begin{array}{l}\text { Estimated } \\
\text { Tillage Date }\end{array}$} & \multirow{2}{*}{$\begin{array}{l}\text { Estimated } \\
\text { Tillage Type }\end{array}$} & \multirow{2}{*}{$\begin{array}{l}\text { Estimated Pesticide } \\
\text { Application Date }\end{array}$} & \multicolumn{2}{|c|}{ Subbasins and Applied Atrazine } & \multirow{2}{*}{$\begin{array}{l}\text { NASS Corn } \\
\text { Plant Dates }\end{array}$} & \multirow{2}{*}{$\begin{array}{c}\% \text { NASS } \\
\text { Planted Area }\end{array}$} \\
\hline & & & Subbasin & $\%$ Atrazine & & \\
\hline 6 April & Not mapped & 16 April & 1 & 1.2 & 16 April & 1 \\
\hline 13 April & Not mapped & 23 April & 8,10 & 2.7 & 23 April & 3 \\
\hline 20 April & Conventional & 30 April & $24,28,33,39,45$ & 9.5 & 30 April & 18 \\
\hline 24 April & No till & 4 May & $11,19,20,23,25,26$ & 9.4 & -- & -- \\
\hline 28 April & Conventional & 8 May & $4,7,9,12,14,21,34,36,38$ & 15.6 & 7 May & 32 \\
\hline 3 May & Conventional & 13 May & $5,16,17,18,32,35,40,42,46,50$ & 26.3 & 14 May & 32 \\
\hline 7 May & No till & 17 May & $30,31,37,43,49,51,52,55$ & 10.6 & -- & -- \\
\hline 11 May & Conventional & 21 May & 6,15 & 3.4 & 21 May & 8 \\
\hline 20 May & Conventional & 30 May & 47,48 & 3.9 & 28 May & 2 \\
\hline 4 June & Not mapped & 14 June & 41 & 3.3 & 4 June & 3 \\
\hline
\end{tabular}


and percentage area for which atrazine was applied correlates closely with the NASS progress report for the approximately $86 \%$ of the crop area for which it was applied.

During the tile drainage setup for the agricultural area, the depth to the tile drain was set at $800 \mathrm{~mm}$, while the time to drain soil to field capacity and time until water enters the channel network after entering tiles were set at $48 \mathrm{~h}$ and $2 \mathrm{~h}$, respectively, based on field information provided by the USDA-ARS NSERL research group (Larose et al., 2007). The SWAT model for the St. Joseph watershed was set up to run on a daily time step, and the SCS curve number method was used for surface runoff computation. Potential evapotranspiration was estimated using the Penman-Monteith method. Channel water routing was simulated using the Muskingum approach. Default simulation (without any calibration) served as the basis for model calibration and validation.

\section{SWAT SimULATIONS}

To assess the initial performance of the model before calibration, a cold simulation or default SWAT run was completed for the calibration (1989-1999) and validation (2000-2004) periods. The statistics used for the model result analysis were the Nash-Sutcliffe efficiency coefficient (NSE) (Nash and Sutcliffe, 1970), the coefficient of determination $\left(\mathrm{R}^{2}\right)$, and the deviation of water yields $(\mathrm{Dv})$ (Neitsch et al., 2002b).

Depending on the modeling objective, it is necessary for the model to be allowed to initialize some years prior to the start of the actual simulation date. Tolson and Shoemaker (2004) used a 2-year warm-up period to provide reasonable initial channel sediment levels, while Mamillapalli (1998) used a 5-year warm-up period to minimize model initialization problems. Flay (2001) recommended a 10-year period to reduce the influence of initial conditions on model results. A 5-year warm up period for hydrology was used in this study.

To ensure good model prediction over varied climatic and environmental conditions, and to reduce simulation bias with respect to isolated rainfall and temperature events, the model was first calibrated for long-term water balance over a 26-year period from 1980 to 2005 to ensure that the total water yield from the basin was close to measured water yield. Measured and simulated water yield were separated into base flow and surface runoff before analysis, using the online Web-based Hydrograph Analysis Tool (WHAT) (Lim et al., 2005). The one-parameter digital filter with parameter value 0.925 was used. The base flow indices (BFI) for measured stream flow data were between 0.55 and 0.60 for the different USGS gauges, while those for their corresponding simulations were between 0.45 and 0.60 .

Subsequent to the long-term model calibration for flow, the model was calibrated for daily stream flow. Three USGS gauges were used for the model calibration for a period of 11 years from 1989 to 1999 . The three gauges are located on the St. Joseph River near Fort Wayne, Indiana (gauge 4180500), on Cedar Creek near Cedarville, Indiana (gauge 4180000), and on the St. Joseph River near Newville, Indiana (gauge 4178000) (fig. 1). The model was calibrated by adjusting one sensitive variable at a time and applying the changes piecewise to the whole watershed. Non-unique variables were changed by subbasin and soil group, while sensitive variables such as those related to soil properties were changed by soil type and layer at HRU levels. The stream flow validation was performed for the time period from 2000 to 2004 using measured data at the calibration stations and an additional USGS gauge station (USGS 4177810, fig. 1).

Atrazine calibration and validation followed stream flow calibration and validation. To develop the annual variability in atrazine application rate in SWAT, average application rates were calculated from NASS pesticide reports to represent different years in the simulation. The average application rates for the 5-year crop rotations were 1.50, $1.50,1.41,1.44$, and $1.46 \mathrm{~kg} \mathrm{ha}^{-1}$, respectively. The atrazine applied by percentage area, and temporal and spatial trends were simulated as discussed previously. SWAT simulations of atrazine losses were compared to measured data (1996-2004) obtained from the SJRWI group and measured data (2000-2004) obtained from the Three Rivers Filtration Plant at Fort Wayne, Indiana.

\section{Results ANd Discussion}

\section{Stream Flow Calibration and Validation}

During the calibration process, eight sensitive variables were modified for hydrology. The most sensitive parameters included the SCS runoff curve number for moisture condition II (CN2), soil evaporation compensation factor (ESCO), surface runoff lag time (SURLAG), the coefficient controlling the impact of low flow storage time on water routing (MSK_CO2), and groundwater recession factor (ALPHA_BF). The default and modified variable values are listed in table 2 . Daily and monthly model simulations were run during the calibration and validation periods. Tables 3 and 4 provide the daily and monthly statistical results for the stream flow calibration and validation periods. Figures 3 and 4 show daily stream flow hydrographs for calibration and validation periods for USGS gauge 4180500, near the St. Joseph watershed outlet at Ft. Wayne, Indiana (fig. 1).

The averages of $\mathrm{R}^{2}$ and NSE for all gauges during stream flow calibration were 0.59 and 0.56 , respectively, for daily simulations and 0.75 and 0.70 , respectively, for monthly simulations, while average $\mathrm{R}^{2}$ and NSE for the validation period were 0.63 and 0.56 , respectively, for daily simulations and 0.80 and 0.78 , respectively, for monthly simulations. The results following validation show improved NSE and $\mathrm{R}^{2}$ and a decrease in Dv. Monthly model performances were superior to daily performances, as indicated by greater NSE values.

The model performance was further evaluated for statistical significance using the paired t-test on the $\mathrm{R}^{2}$ values. Three gauges used for the stream flow calibration and validation had test statistics greater than the critical t-value, indicating that the model predictions explained significant variations in the measured data. However, the null hypothesis for USGS gauge 4177810, used in the model validation, could not be rejected if its data points were included in the model analysis. The result for this gauge could be the impact of Hamilton Lake, located upstream from the gauge, and the lack of information to calibrate the outflow from the reservoir. The model performance efficiency for hydrology was satisfactory, considering inherent uncertainties in the flow data. However, the model showed some underpredictions of peak flow values, especially during the winter and early spring months, partly due to snow melt impact that was not well accounted for in the model. 
Table 2. SWAT model variables and their default and calibrated values used in this study.

\begin{tabular}{|c|c|c|c|c|c|}
\hline \multicolumn{2}{|c|}{ Variable } & Description & Default Value & Calibrated Value & Input File \\
\hline \multirow[t]{7}{*}{ Flow } & $\mathrm{CN} 2$ & $\begin{array}{l}\text { SCS runoff CN for } \\
\text { moisture condition II }\end{array}$ & 45 to 85 & $\begin{array}{l}\text { Increase of } 5 \text { for HRUs with urban, } \\
\text { residential, and transportation land use }\end{array}$ & mgt \\
\hline & ESCO & Soil evaporation compensation factor & 0.95 & 0.90 &.$b s n$ \\
\hline & SURLAG & Surface runoff lag time & $4 \mathrm{~d}$ & $1 \mathrm{~d}$ &.$b s n$ \\
\hline & CANMX & Maximum water storage in canopy & $0 \mathrm{~mm}$ & $\begin{array}{c}60 \mathrm{~mm} \text { for HRUs with deciduous } \\
\text { and wetland forest }\end{array}$ & .hru \\
\hline & MSK_CO2 & $\begin{array}{l}\text { Coefficient for impact of } \\
\text { low flow storage time }\end{array}$ & 3.5 & 2.5 &.$b s n$ \\
\hline & SOL_AWC & $\begin{array}{l}\text { Soil available water capacity } \\
\text { (by layer) }\end{array}$ & $\begin{array}{r}0.12 \text { to } 0.19 \\
\mathrm{~mm} \mathrm{~mm}^{-1}\end{array}$ & $\begin{array}{l}\text { Layer } 1 \text { of Agric soils B and C } \\
\text { increased by } 0.10\end{array}$ & sol \\
\hline & SOL_K & $\begin{array}{l}\text { Soil saturated hydraulic conductivity } \\
\text { (by layer) }\end{array}$ & $\begin{array}{l}2.6 \text { to } 52 \\
\mathrm{~mm} \mathrm{~h}^{-1}\end{array}$ & $\begin{array}{l}\text { Layer } 1 \text { of Agric soils B and C } \\
\text { increased by } 10 \%\end{array}$ & .sol \\
\hline \multirow[t]{2}{*}{ Base flow } & ALPHA_BF & Groundwater recession factor & $0.048 \mathrm{~d}$ & $0.30 \mathrm{~d}$ &. $\mathrm{gw}$ \\
\hline & GW_DELAY & Groundwater delay & $31 \mathrm{~d}$ & $31 \mathrm{~d}$ &. $\mathrm{gw}$ \\
\hline \multirow[t]{3}{*}{ Tile drainage } & DRAIN & Depth to subsurface drain & $0.0 \mathrm{~mm}$ & $800 \mathrm{~mm}$ & .mgt \\
\hline & TRAIN & Time to drain the soil to field capacity & $0.0 \mathrm{~h}$ & $48 \mathrm{~h}$ & .mgt \\
\hline & GRAIN & Drain tile lag time & $0.0 \mathrm{~h}$ & $2 \mathrm{~h}$ & .mgt \\
\hline
\end{tabular}

Table 3. Model performance statistics for stream flow calibration (1989-1999).

\begin{tabular}{|c|c|c|c|c|c|c|c|c|}
\hline \multirow[b]{2}{*}{ Station Location } & \multirow{2}{*}{$\begin{array}{c}\text { USGS } \\
\text { Gauge } \\
\text { No. }\end{array}$} & \multirow{2}{*}{$\begin{array}{c}\text { Drainage } \\
\text { Area } \\
\text { (ha) }\end{array}$} & \multicolumn{3}{|c|}{$\begin{array}{l}\text { Daily Stream Flow } \\
\text { Simulation Statistics }\end{array}$} & \multicolumn{3}{|c|}{$\begin{array}{l}\text { Monthly Stream Flow } \\
\text { Simulation Statistics }\end{array}$} \\
\hline & & & $\mathrm{R}^{2}$ & NSE & $\operatorname{Dv}(\%)$ & $\mathrm{R}^{2}$ & NSE & Dv $(\%)$ \\
\hline St. Joseph River near Newville & 4178000 & 158,861 & 0.55 & 0.5 & 8 & 0.76 & 0.74 & 8 \\
\hline Cedar Creek near Cedarville & 4180000 & 69,623 & 0.61 & 0.58 & 18 & 0.73 & 0.68 & 18 \\
\hline St. Joseph River near Ft. Wayne & 4180500 & 272,604 & 0.61 & 0.59 & 18 & 0.77 & 0.69 & 18 \\
\hline \multicolumn{3}{|c|}{ Mean values } & 0.59 & 0.56 & 14.7 & 0.75 & 0.7 & 14.6 \\
\hline
\end{tabular}

Table 4. Model performance statistics for stream flow validation (2000-2004).

\begin{tabular}{|c|c|c|c|c|c|c|c|c|}
\hline \multirow[b]{2}{*}{ Station Location } & \multirow{2}{*}{$\begin{array}{c}\text { USGS } \\
\text { Gauge } \\
\text { No. }\end{array}$} & \multirow{2}{*}{$\begin{array}{c}\text { Drainage } \\
\text { Area } \\
\text { (ha) }\end{array}$} & \multicolumn{3}{|c|}{$\begin{array}{l}\text { Daily Stream Flow } \\
\text { Simulation Statistics }\end{array}$} & \multicolumn{3}{|c|}{$\begin{array}{l}\text { Monthly Stream Flow } \\
\text { Simulation Statistics }\end{array}$} \\
\hline & & & $\mathrm{R}^{2}$ & NSE & Dv $(\%)$ & $\mathrm{R}^{2}$ & NSE & $\operatorname{Dv}(\%)$ \\
\hline Fish Creek near Artic & 4177810 & 23,727 & 0.63 & 0.44 & -0.5 & 0.83 & 0.81 & -8.2 \\
\hline St. Joseph River near Newville & 4178000 & 158,861 & 0.64 & 0.58 & -4.8 & 0.8 & 0.8 & -4.8 \\
\hline Cedar Creek near Cedarville & 4180000 & 69,623 & 0.62 & 0.59 & 20.3 & 0.78 & 0.73 & 20.2 \\
\hline St. Joseph River near Ft. Wayne & 4180500 & 272,604 & 0.61 & 0.61 & 7.6 & 0.79 & 0.78 & 7.4 \\
\hline \multicolumn{3}{|c|}{ Mean values } & 0.63 & 0.56 & 5.6 & 0.8 & 0.78 & 3.6 \\
\hline
\end{tabular}

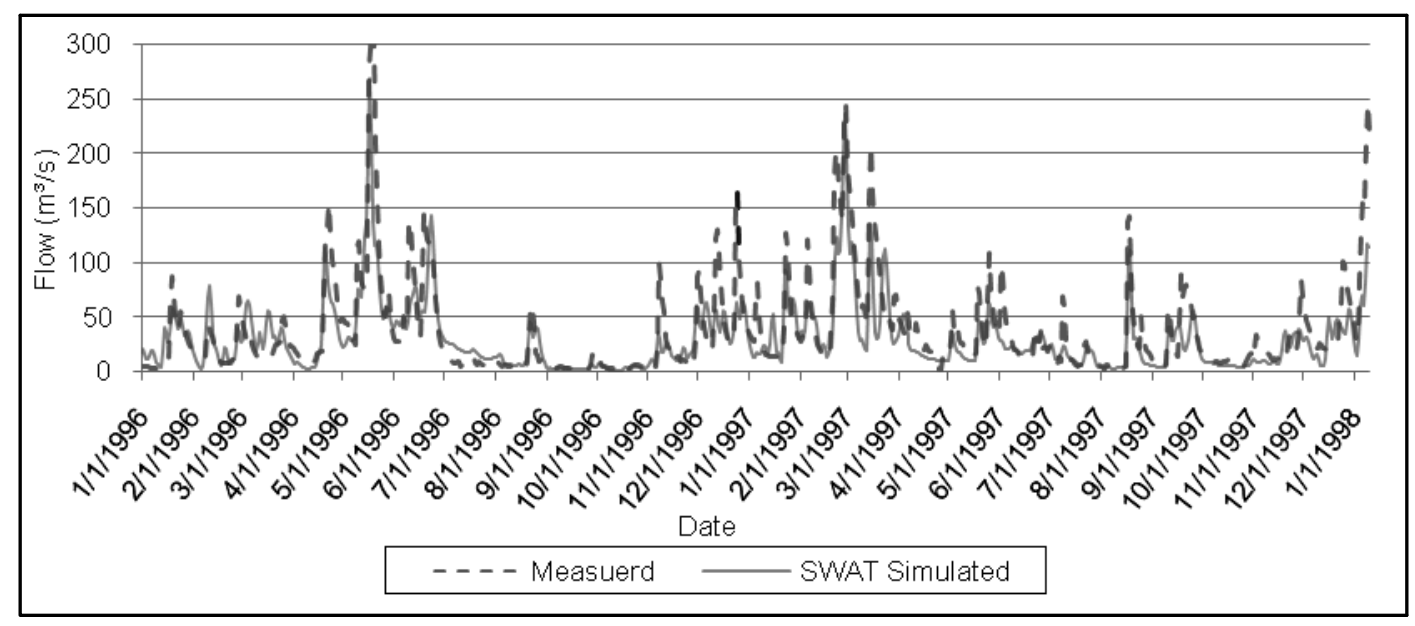

Figure 3. Daily stream flow hydrograph for calibration period for the St. Joseph watershed at USGS gauge 4180500 near Ft. Wayne, Indiana.

The model parameter values and performance statistics were comparable to values obtained by other researchers, such as Neitsch et al. (2002b), who used SWAT to simulate pesticide concentrations in the Sugar Creek watershed,
Indiana, and obtained $\mathrm{R}^{2}$ of 0.59 and NSE of 0.47 for daily stream flow calibration and $\mathrm{R}^{2}$ of 0.75 and NSE of 0.74 for the validation period. Vazquez-Amabile et al. (2006) obtained $\mathrm{R}^{2}$ ranges from 0.50 to 0.66 and 0.66 to 0.76 for 


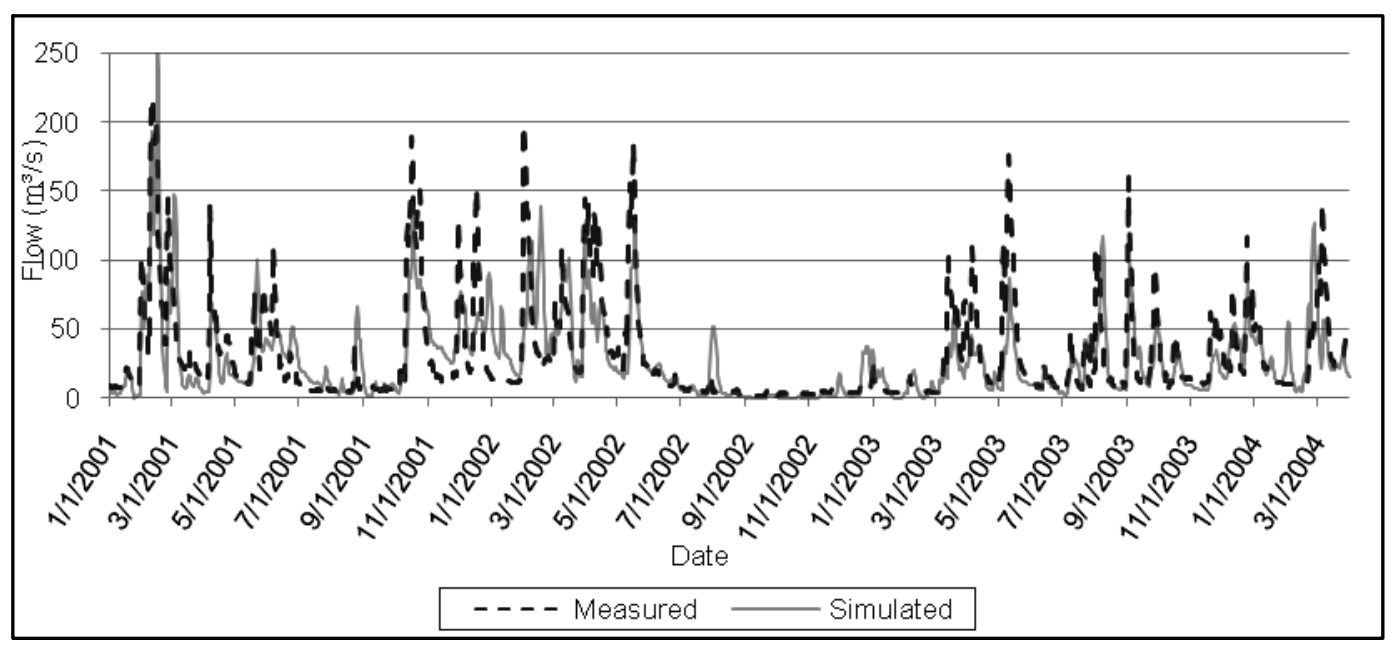

Figure 4. Daily stream flow hydrograph for validation period for the St. Joseph watershed at USGS gauge 4180500 near Ft. Wayne, Indiana.

daily and monthly calibration, respectively, while NSE values ranged from 0.33 to 0.65 and 0.64 to 0.74 for daily and monthly validation simulation, respectively, during atrazine-related research in the same watershed. Larose et al. (2007) reported similar results for daily and monthly NSE for the Cedar Creek subbasin within the St. Joseph watershed. White and Chaubey (2005) and Kirsch et al. (2002) reported similar results for stream flow calibration using SWAT for water-sheds in Arkansas and Wisconsin, respectively. The slight difference in average $\mathrm{R}^{2}$ and NSE, in comparison with other researchers, assuming similar uncertainties, may be a result of differences in the data used for the calibration and validation periods, and possibly an enhanced impact from the integration of mapped tillage trends.

The comparison of model results with other research results is limited, however, since factors such as size of watershed, number of subbasins, type of soils and land use, level of uncertainties in stream flow and water quality data, as well the approach and years of model calibration and validation influence the model efficiency and performance statistics. According to the USGS, conditions of the instrumentation, record compilation methods, and other factors could result in 5\% to $15 \%$ error in observed flow data (USGS, 2006). Few or limited network of precipitation and temperature gauges could reduce model performance efficiency, since the density of climate gauges determines the variability in processes such as surface runoff. In such watersheds, modelers may consider employing the use of remotely sensed data such as NEXRAD datasets to optimize runoff prediction.

Limited availability or errors in climatic and stream flow data can introduce uncertainties in model simulations, resulting in either over- or underestimated model performance measures. Since different data sources for different watersheds have different levels of errors, model performance statistics reported by different researchers could be either over- or underestimated. For these reasons, strict comparison of $\mathrm{R}^{2}$ and NSE may not be ideal.

\section{Atrazine Calibration and Validation}

Atrazine loss was calibrated for the years 1996 to 1999 and validated from 2000 to 2004 with a 5-year atrazine warm-up period for each simulation. The initial study of simulated atrazine concentrations from the default SWAT run indicated very high levels compared to observed data. For a few data points, timing of simulated and measured peak concentrations did not coincide. This situation arises from issues related to atrazine application timing, rate, and the percentage of atrazine that percolates into subsurface soils or is transferred through surface runoff and tile drains. The results of simulations from 3-day lag and 10-day lag atrazine application after tillage indicated that the 10-day lag application produced better simulated atrazine results and better matched NASS corn plant progress trends. The 3-day lag atrazine application resulted in NSE of -0.10 and 0.22 for daily and monthly validation for the St. Joseph watershed outlet at Ft. Wayne, compared to -0.04 and 0.35 obtained for the 10-day lag atrazine application. Thus, a 10-day lag in atrazine application after tillage was used in this study. The other sensitive variable that affected the amount of atrazine in runoff was the pesticide percolation coefficient (PERCOP), which was calibrated to an optimum value of 0.04 (table 5).

The model performance at the different water quality points depends on a number of factors, such as the simulated amount and location of applied atrazine compared to actual management situations at various field locations. Data points directly on or very close to the St. Joseph River with larger drainage areas tend to have the highest $\mathrm{R}^{2}$ and NSE values, as atrazine concentrations are routed from all subbasins into the river. For other sampling points, the accuracy depends on whether their subbasins had atrazine applied in both actual fields and in the simulation. If a different pesticide (e.g., metolachlor) was applied in a subbasin, then the accuracy for this point would not be high. This explains the performance of atrazine simulations in which the sample points 100, 123, 126 , and 130, directly on the St. Joseph River or on large

Table 5. Modified SWAT input variables for atrazine calibration.

\begin{tabular}{ccccc}
\hline Variable & Description & Default & Calibrated & Input \\
PERCOP & $\begin{array}{c}\text { Partitioning of soluble } \\
\text { pesticide between percolate } \\
\text { and surface runoff }\end{array}$ & 0.50 & 0.04 & File \\
\hline WOF & Wash-off fraction & 0.45 & 0.45 & Pest.dbf \\
\hline
\end{tabular}


Table 6. SWAT model performance statistics for atrazine calibration (1996-1999).

\begin{tabular}{|c|c|c|c|c|c|c|c|}
\hline \multirow{2}{*}{$\begin{array}{l}\text { Sample } \\
\text { Point }\end{array}$} & \multirow{2}{*}{$\begin{array}{l}\text { Upstream } \\
\text { Area (ha) }\end{array}$} & \multicolumn{3}{|c|}{ Daily } & \multicolumn{3}{|c|}{ Monthly } \\
\hline & & $\mathrm{R}^{2}$ & NSE & RMSE & $\mathrm{R}^{2}$ & NSE & RMSE \\
\hline 100 & 64,180 & 0.5 & 0.42 & 2.02 & 0.68 & 0.5 & 2.37 \\
\hline 104 & 9,909 & 0.17 & -0.67 & 3.28 & 0.28 & -1.51 & 4.89 \\
\hline 123 & 162,000 & 0.30 & 0.23 & 2.02 & 0.43 & 0.36 & 1.33 \\
\hline 124 & 27,280 & 0.06 & -0.3 & 3.16 & 0.57 & 0.3 & 1.33 \\
\hline 125 & 27,880 & 0.21 & -0.18 & 1.74 & 0.63 & 0.29 & 1.18 \\
\hline 126 & 38,660 & 0.27 & 0.06 & 1.77 & 0.57 & -0.75 & 2.00 \\
\hline 127 & 6,252 & 0.10 & -0.13 & 3.8 & 0.47 & 0.35 & 1.79 \\
\hline 128 & 6,770 & 0.01 & -0.39 & 3.59 & 0.26 & -0.33 & 2.33 \\
\hline 130 & 9,348 & 0.47 & 0.32 & 2.03 & 0.54 & 0.39 & 2.36 \\
\hline 131 & 96,100 & 0.13 & -0.37 & 3.42 & 0.13 & -0.22 & 2.47 \\
\hline \multicolumn{2}{|c|}{ Numeric mean } & 0.22 & -0.1 & 2.68 & 0.46 & -0.06 & 2.21 \\
\hline
\end{tabular}

tributaries, had the highest NSE compared to other points. The SWAT performance statistics for atrazine simulation during the calibration and validation periods are summarized in tables 6 and 7, respectively. Although the statistical values are not very large, they are within the range for pesticide modeling analysis for $\mathrm{R}^{2}$ and NSE values reported in some publications. A comparison of total/average measured and simulated concentrations/loads was used during the analysis.

The $\mathrm{R}^{2}$ and NSE values obtained from the analysis show a higher accuracy for average monthly atrazine simulations than for daily simulated concentrations. Since the atrazine application dates used in the model were derived from sources such as mapped tillage layers, which were in turn processed from MODIS and Landsat data, atrazine timing errors could be introduced if the modeled application dates greatly exceed the actual atrazine application dates. These uncertainties in the tillage, planting, and atrazine application dates could range from a few days to weeks. While these errors could affect daily simulated farm activities, their effect on weekly and monthly average simulations are reduced.

The NLCD agricultural areas did not specify exactly where corn or soybean crops were located, and had to be split according to NASS average ratios. This could introduce some uncertainties since, in reality, the actual fields, pesticide types, application amount, and timing were un-
Table 7. SWAT model performance statistics for atrazine validation (2000-2004).

\begin{tabular}{|c|c|c|c|c|c|c|c|}
\hline \multirow{2}{*}{$\begin{array}{c}\text { Sample } \\
\text { Point }\end{array}$} & \multirow{2}{*}{$\begin{array}{l}\text { Upstream } \\
\text { Area (ha) }\end{array}$} & \multicolumn{3}{|c|}{ Daily } & \multicolumn{3}{|c|}{ Monthly } \\
\hline & & $\mathrm{R}^{2}$ & NSE & RMSE & $\mathrm{R}^{2}$ & NSE & RMSE \\
\hline 100 & 64,180 & 0.28 & -0.17 & 2.01 & 0.22 & -4.90 & 2.40 \\
\hline 104 & 9,909 & 0.21 & -0.18 & 2.08 & 0.03 & -7.38 & 3.25 \\
\hline 123 & 162,000 & 0.46 & 0.29 & 1.91 & 0.33 & 0.08 & 1.26 \\
\hline 124 & 27,280 & 0.09 & -0.41 & 2.25 & 0.15 & -0.65 & 1.44 \\
\hline 125 & ,880 & 0.02 & -0.56 & 1.68 & 0.42 & -0.31 & 1.03 \\
\hline 126 & 38,660 & 0.29 & 0.01 & 1.58 & 0.34 & -3.11 & 1.77 \\
\hline 127 & 6,252 & 0.12 & -0.41 & 2.88 & 0.12 & -6.95 & 3.70 \\
\hline 128 & 6,770 & 0.15 & -0.49 & 2.92 & 0.18 & -0.95 & 1.57 \\
\hline 130 & 348 & 0.36 & 0.14 & 2.26 & 0.55 & 0.00 & 1.44 \\
\hline 131 & 96,100 & 0.21 & -0.13 & 2.29 & 0.27 & -0.26 & 1.66 \\
\hline $\begin{array}{c}\text { Ft. Wayne } \\
\text { outlet }\end{array}$ & 262,000 & 0.35 & -0.04 & 1.98 & 0.63 & 0.34 & 1.29 \\
\hline Jumer & $\operatorname{ean}$ & 0.23 & -0.18 & 2.15 & 0.29 & -2.19 & 1.89 \\
\hline
\end{tabular}

known, and atrazine application in the model could result in imperfect application distribution and the estimation of atrazine concentrations at some sampling stations.

In addition to the previously discussed potential sources of error with respect to tillage, planting, and pesticide application dates and amounts, other model inputs could significantly influence the model simulation outcome. Water quality sampling, sample preservation, and laboratory analysis introduce potential uncertainties in the observed pesticide concentrations. According to Harmel et al. (2006), average calculated uncertainty ranges from $4 \%$ to $48 \%$ for sample collection and from $2 \%$ to $16 \%$ for sample preservation, while laboratory analysis contributes $5 \%$ to $21 \%$ of the uncertainty in water quality data. Individual procedures and constituents being sampled have varied levels of uncertainty depending on the best or worst case scenarios for each process. Thus, the resulting water quality data would have some uncertainties that could influence model simulations during calibration and validation. For instance, the probable error range is $8 \%$ to $104 \%$ for dissolved nutrient data and $8 \%$ to $110 \%$ for total nutrients (Harmel et al., 2006). Assuming that the ranges of these uncertainties are also applicable to pesticide data, cumulative uncertainties in model parameters could be expected in this study.

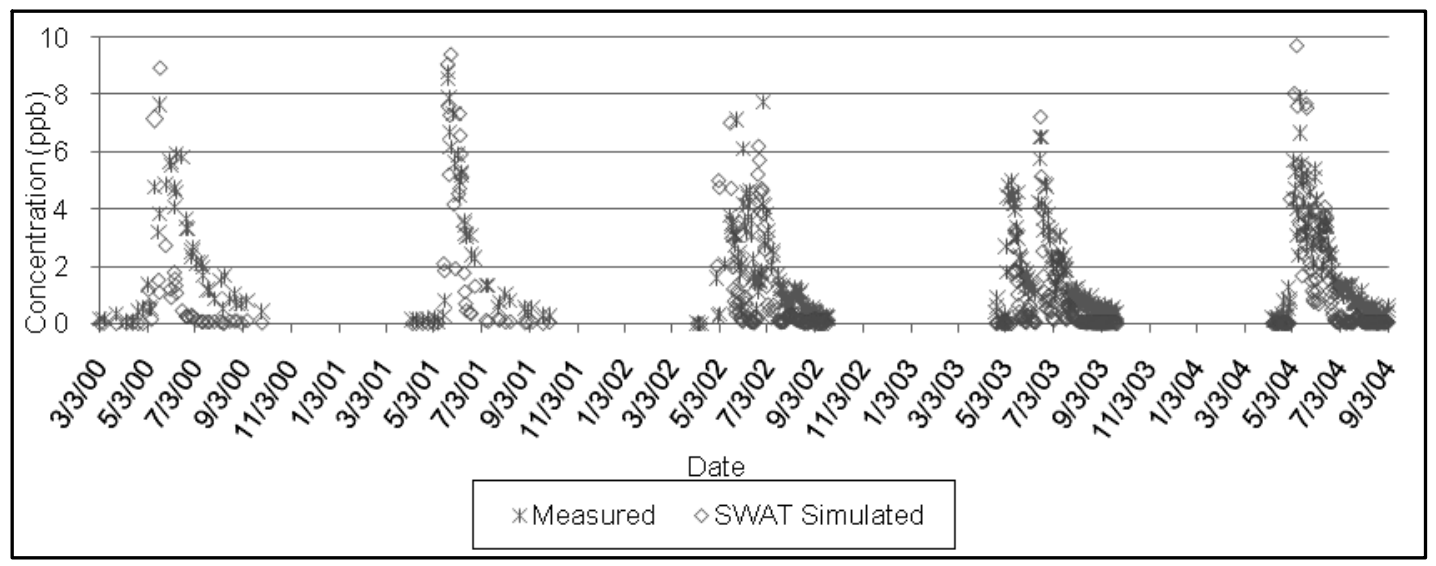

Figure 5. Daily measured and SWAT simulated in-stream atrazine concentrations in the St. Joseph watershed outlet at Ft. Wayne for the validation period (2000-2004). 


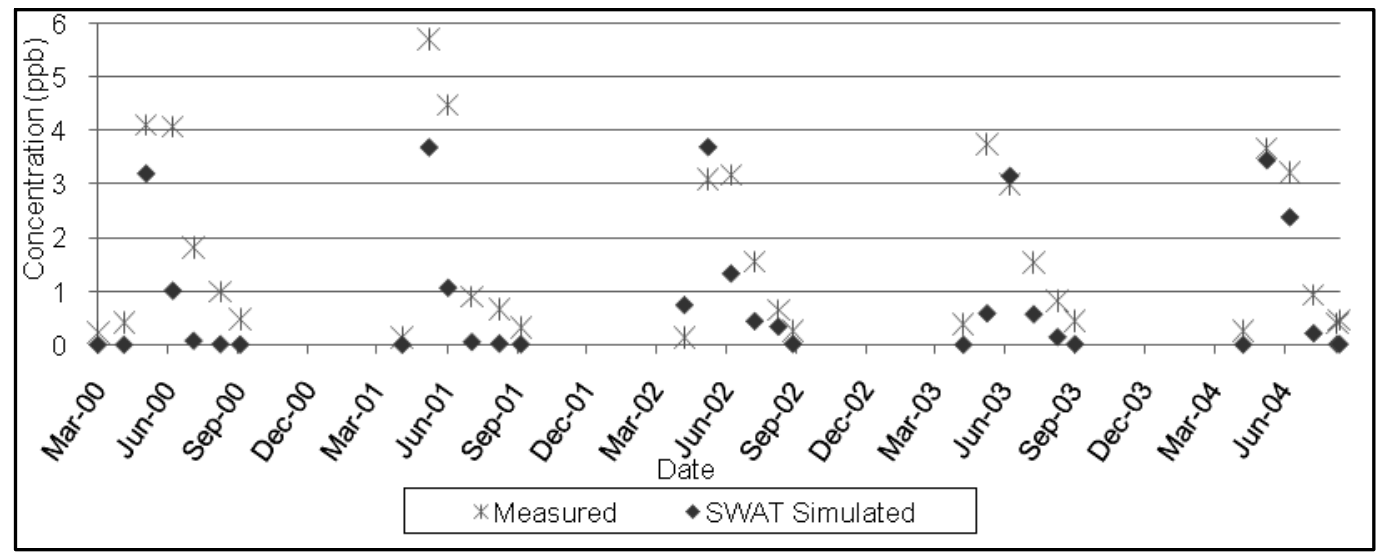

Figure 6. Monthly measured and SWAT simulated in-stream atrazine concentrations in the St. Joseph watershed outlet at Ft. Wayne for the validation period (2000-2004).

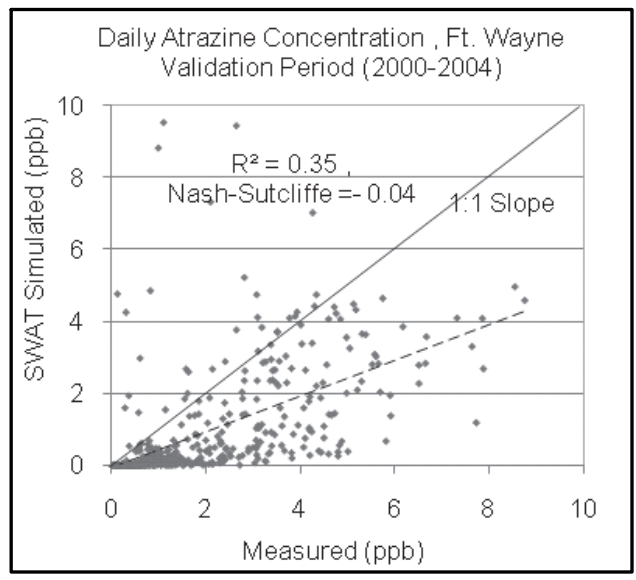

(a)

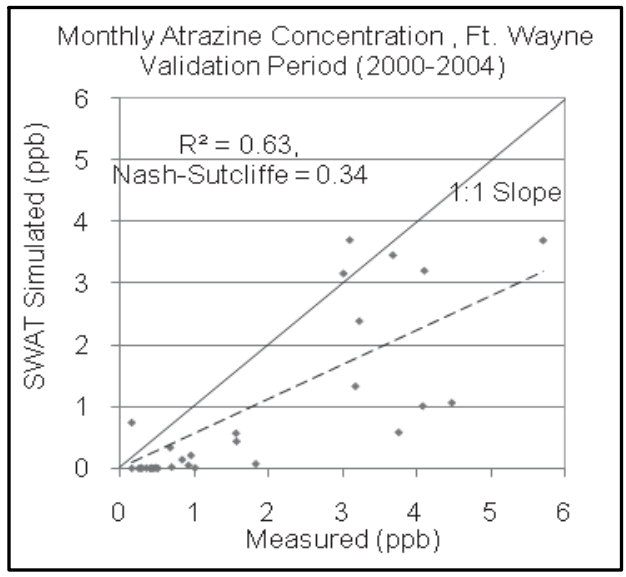

(b)

Figure 7. Scatter plot for (a) daily and (b) monthly measured and simulated in-stream atrazine concentration (ppb) for the validation period for the St. Joseph watershed outlet at Ft. Wayne, Indiana.

Figures 5 and 6 show daily and monthly time series plots of simulated and measured atrazine concentrations at the St. Joseph watershed outlet at Ft. Wayne, and the corresponding scatter plots are shown in figure 7 . These figures show that the simulated atrazine concentrations follow similar patterns as the measured atrazine concentrations. As is common for models and considering the sources of uncertainty discussed in the preceding paragraphs, there are variations at discrete sampling points; however, high atrazine concentrations are prominent during May to July (figs. 5 and 6) when heavy rainfall results in high runoff volumes (figs. 3 and 4).

The statistics for the prediction of atrazine concentration were within ranges reported by other researchers, such as Neitsch et al. (2002b) and Vazquez-Amabile et al. (2006). Neitsch et al. (2002b) reported $\mathrm{R}^{2}$ of 0.41 for daily atrazine simulations during validation for the Sugar Creek watershed, Indiana, while Vazquez-Amabile et al. (2006) reported $\mathrm{R}^{2}$ of 0.27 for daily atrazine during validation for the St. Joseph watershed outlet at Fort Wayne. This research obtained $\mathrm{R}^{2}$ of 0.35 for daily atrazine validation for the watershed outlet at Fort Wayne. The NSE value obtained for Cedar Creek at SJRWI sample point 100 was 0.42 (table 6) and was similar to the model efficiency reported by Vazquez-Amabile et al. (2006) and Larose et al. (2007) for this location. The NSE values obtained for daily and monthly simulations for all ten sample points ranged from -0.67 to 0.42 and -1.51 to 0.50 , respectively, for calibration and from -0.56 to 0.29 and -7.38 to 0.34 , respectively, for validation. The varying range of model performance at different sample stations is not unusual, since when many sampling stations are used for model calibration, model performance will deteriorate at some stations while at other stations it is improved (White and Chaubey, 2005).

The $t$-test performed on atrazine calibration and validation results show that for all but two sampling stations, the t-test statistic was greater than the critical t-value, resulting in the rejection of the null hypothesis and indicating that the simulated data significantly explained variability in the measured data. The general simulated and measured atrazine concentrations at the watershed outlet (figs. 5 and 6) were comparable to one another.

While predicted and measured atrazine concentrations for most of the year were generally below $3 \mathrm{ppb}$, seasonal high values exceeding $3 \mathrm{ppb}$ are common during early rainfall events in the cropping season (May to July), when applied atrazine is washed off into streams, as evident by measured maximum concentration levels ranging from 8.6 to $237.5 \mathrm{ppb}$ in several Indiana watersheds (EPA, 2007). Both simulated 
Table 8. Simulated and measured first dates when atrazine concentrations spike above 3 ppb at the Three Rivers Filtration Plant (Ft. Wayne, Ind.) from 2000 to 2004.

\begin{tabular}{ccc}
\hline & \multicolumn{2}{c}{ Atrazine Concentrations $(\mathrm{ppb})$} \\
\cline { 2 - 3 } Date & Simulated & Measured \\
\hline 12 May 2000 & 4.46 & 4.76 \\
16 May 2001 & 4.26 & 0.29 \\
21 May 2001 & 4.97 & 8.56 \\
10 May 2002 & 7.33 & 2.09 \\
17 May 2002 & 4.10 & 3.77 \\
6 May 2003 & 0.37 & 4.44 \\
12 June 203 & 8.83 & 0.98 \\
5 May 2004 & 2.21 & 4.34 \\
7 May 2004 & 3.66 & 5.31 \\
\hline
\end{tabular}

and measured data at the Three Rivers Filtration Plant at Fort Wayne, Indiana (figs. 5 and 6) show that atrazine concentrations in surface water system could stay above the $3 \mathrm{ppb}$ between May and July, especially because of its long halflife of six months in water (WHO, 1996). Important information, however, is to be able to identify when atrazine levels begin to reach levels above $3 \mathrm{ppb}$ and how long it stays above this level during the cropping season. A comparison of dates of first spikes in atrazine concentration level above $3 \mathrm{ppb}$ for measured and simulated data is shown in table 8 .

The results show that SWAT-simulated concentrations generally reached $3 \mathrm{ppb}$ or greater on or around the date when measured concentrations also reached such levels. Thus, the model was able to predict the timing of atrazine pollution "alert" conditions within a few days of actual measured pollution levels, except in 2003. The discrepancy in the timing of atrazine peaks could arise from the fact that the pattern and levels of simulated spikes were completely based on predicted runoff and atrazine application trends. Low simulated runoff volume (e.g., $12.5 \mathrm{~m}^{3} \mathrm{~s}^{-1}$ for 12 June 2003) results in higher concentration, while high runoff volume (e.g., $36.6 \mathrm{~m}^{3} \mathrm{~s}^{-1}$ for 06 May 2003) results in dilution and a lower atrazine concentration. Thus, atrazine application timing and accuracy of precipitation data are important factors in the simulation of pesticide pollution. Nonetheless, these spike trends provide important information on the likely dates and concentration levels for atrazine pollution.

The result of the simulation underscores the potential application in early warning prediction for atrazine pollution management, when the calibrated SWAT model is updated with current input data and real-time tillage management information. Current precipitation data from sources such as NEXRAD, together with immediate future weather data estimates, could be updated into an already parameterized SWAT model for immediate future atrazine concentration predictions. Predicted atrazine concentration levels and identified critical areas provide early warning information necessary for stakeholders such as water treatment industries, EPA, and USDA to evaluate water treatment and best management practices.

\section{Summary ANd CONClusions}

Tillage practices mapped from Landsat TM and MODIS data were integrated into AVSWAT 2005 agricultural management scenarios in simulating potential atrazine concentrations in rivers in the St. Joseph watershed. The calibrated and validated model performed satisfactorily in comparison with measured data. In particular, average daily and monthly NSE values for hydrology were 0.56 and 0.70 , respectively, for calibration and 0.55 and 0.79 , respectively, for validation, attributed partly to improved tillage representation in the model. Model efficiency for simulated atrazine concentrations was highly dependent on tillage practices as well as the timing, rate, and area of atrazine application, with respect to rainfall events and proximity to streams and rivers. Model performance for water quality stations on or near the St. Joseph River were better than those farther away, potentially because atrazine in the watershed is channeled through subbasins into the St. Joseph River. The simulated atrazine concentration at the watershed outlet showed significant similarity with measured data, with NSE of -0.04 and 0.34 , respectively, for daily and monthly simulations. However, hydrologic modeling is prone to inherent cumulative uncertainties from climatic, stream flow, and water quality data.

Predicted critical concentration levels above $3 \mathrm{ppb}$, during the growing season, were mostly within days of such levels in the measured data. This information is useful in the potential application of SWAT modeling in early warning prediction of agricultural nonpoint-source pollution. A parameterized SWAT model could be updated with real-time weather data and ongoing seasonal agricultural activities, as captured by remote sensing technology, to predict immediate and near-future environmental impacts of such agricultural practices in an area.

While remote sensing technology now makes it possible to map important agricultural practices and soil properties such as crop residue cover, soil moisture, and soil surface temperature, the challenge is the need for the successful integration of such data into hydrologic models to effectively simulate their impact on hydrologic processes and NPS pollution. Hydrologic models need to be enhanced to allow the automatic upload of such non-default layers mapped from remotely sensed data to help efficiently distribute layer attributes to appropriate HRUs.

\section{ACKNOWLEDGEMENTS}

Funding for this project was provided by USDA-CSREES through an Integrated Water Quality Project (Grant No. 015113-03876), and data were obtained from the Purdue Terrestrial Observatory (PTO), the St. Joseph River Watershed Inititiative (SJRWI), and the Three Rivers Filtration Plant at Fort Wayne. We are thankful to Dr. Gilbert Rochon, Dr. A. G. Vazquez, and Dr. Dennis Flanagan. Comments provided by four anonymous reviewers greatly improved the initial verison of the manuscript.

\section{REFERENCES}

Adeuya, M., R. K., K. J. Lim, B. A. Engel, and M. A. Thomas. 2005. Modeling the average annual nutrient losses of two watersheds in Indiana using GLEAMS-NAPRA. Trans. ASAE 48(5): 1739-1749.

Arnold, J. G., R. Srinavasan, R. S. Muttiah, and J. R. Williams. 1998. Large-area hydrologic modeling and assessment: Part I. Model development. JAWRA 34(1): 73-89.

Atwood, J. D., D. W. Goss, R. L. Kellogg, T. A. Pitts, S. R. Potter, and S. Wallace. 2000. The NRCS national nutrient loss modeling project: Preliminary results for corn east of the Rocky Mountains. Unpublished. 
Chung, S. O., A. D. Ward, and C. W. Schalk. 1992. Evaluation of the hydrologic component of the ADAPT water table management model. Trans. ASAE 35(2): 571-579.

CTIC. 1998. Crop residue management executive summary. West Lafayette, Ind.: Conservation Technology Information Center.

Di Luzio, M., R. Srinivasan, J. G. Arnold, and S. L. Neitsch. 2002. ArcView interface for SWAT2000. BRC Report 02-07. Temple, Tex.: Blackland Research and Extension Center.

EPA. 2005. Protecting water quality from agricultural runoff. EPA 841-F-05-001. Washington, D.C.: U.S. EPA.

EPA. 2007. Ecological watershed monitoring program. Washington, D.C.: U.S. EPA. Available at: www.epa.gov/pesticides/ reregistration/atrazine/atrazine_update.htm\#ewmp. Accessed 8 May 2008.

Flay, R. B. 2001. Modeling nitrates and phosphates in agricultural watersheds with the soil and water assessment tool. Available at: www.waterscape.org/pubs/tech_swat/SWAT_Review.doc. Accessed 30 December 2006.

Gitau, M. W., T. L. Veith, and W. J. Gburek. 2004. Farm-level optimization of BMP placement for cost-effective pollution reduction. Trans. ASAE 47(6): 1923-1931.

Gorneau, W. S., T. G. Franti, B. L. Benham, and S. D. Comfort. 2001. Reducing long-term atrazine runoff from south central Nebraska. Trans. ASAE 44(1): 45-52.

Gowda, P. H., R. T. Peters, and T. A. Howell. 2005. Mapping tillage practices in the Texas panhandle with Landsat thematic mapper (TM) data. Wetting Front 7(2): 5-7. Bushland, Tex.: USDAARS Conservation and Production Research Laboratory.

Harmel, R. D., R. J. Cooper, R. M. Slade, R. L. Haney, and J. G. Arnold. 2006. Cumulative uncertainty in measured streamflow and water quality data for small watersheds. Trans. ASABE 49(3): 689-701.

Huber, W. 1993. Ecological relevance of atrazine in aquatic systems. Environ. Toxicol. Chem. 12(10): 1865-1881.

Johnson, B., F. Whitford, L. Hahn, D. Flakne, J. Frankenberger, C. Janssen, and T. Bailey. 2004. Atrazine and drinking water: Understanding the needs of farmers and citizens. West Lafayette, Ind.: Purdue University Extension. Available at: http://btny.purdue.edu/Pubs/PPP/PPP-66.pdf.

Kirsch, K., A. Kirsch, and J. G. Arnold. 2002. Predicting sediment and phosphorus loads in the Rock River basin using SWAT. Trans. ASAE 45(6): 1757-1769.

Laflen, J. M., L. J. Lane, and G. R. Foster. 1991. WEPP: A new generation of erosion prediction technology. J. Soil and Water Cons. 46(1): 34-38.

Larose, M., G. C. Heathman, L. D. Norton, and B. A. Engel. 2007. Hydrologic and atrazine simulation of the Cedar Creek watershed using the SWAT model. J. Environ. Qual. 36(2): 521-531.

Lim, K. J., B. A. Engel, Z. Tang, Z., J. Choi, K. S. Kim, S. Muthukrishnan, and D. Tripathy. 2005. Automated web GIS based hydrograph analysis tool, WHAT. JAWRA 41(6): 1407-1416.
Mamillapalli, S. 1998. Effect of spatial variability on river basin streamflow modeling. PhD diss. West Lafayette, Ind.: Purdue University.

Nash, J. E., and J. V. Sutcliffe. 1970. River flow forecasting through conceptual models: Part I. A discussion of principles. J. Hydrol. 10(3): 282-290.

NASS. 2004. Indiana agricultural statistics. Washington, D.C.: USDA National Agricultural Statistics Service. Available at: www.nass.usda.gov/in/publications.html. Accessed 20 December 2006.

Neitsch, S. L., J. G. Arnold, J. R., Kiniry, J. R. Williams, and K. W. King,. 2002a. Soil and water assessment tool theoretical documentation. GSWRL Report 02-01. Temple, Tex.: USDA-ARS Grassland, Soil and Water Research Laboratory.

Neitsch, S. L., J. G. Arnold, and R. Srinivasan. 2002b. Pesticides fate and transport predicted by the soil and water assessment tool (SWAT): Atrazine, metolachlor, and trifluralin in the Sugar Creek watershed. BRC Publication No. 2002-03. Washington, D.C.: EPA.

Quansah, J. E. 2007. Early warning system for water quality assessment within agricultural watersheds. PhD diss. West Lafayette, Ind.: Purdue University.

SJRWI. 2006. St. Joseph River watershed management plan: Three states, six counties, one watershed. Fort Wayne, Ind.: St. Joseph River Watershed Initiative.

Titi, A. E. 2003. Soil Tillage in Agroecosystems. Boca Raton, Fla.: CRC Press.

Tolson, B. A., and C. A. Shoemaker. 2004. Watershed modeling of the Cannonsville basin using SWAT2000: Model development, calibration, and validation for the prediction of flow, sediment, and phosphorus transport to the Cannonsville reservoir. Version 1.0. Tech. Report. Ithaca, N.Y.: Cornell University, School of Civil and Environmental Engineering.

USGS. 2006. Scientific investigations report 2006-5036. Washington, D.C.: U.S. Geological Survey.

Vazquez-Amabile, G., B. A. Engel, and D. C. Flanagan. 2006. Modeling and risk analysis of nonpoint-source pollution caused by atrazine using SWAT. Trans. ASABE 49(3): 667-678.

White, K. L., and I. Chaubey. 2005. Sensitivity analysis, calibration, and validations for a multisite and multivariable SWAT model. JAWRA 41(5): 1077-1089.

WHO. 1996. Atrazine. WHO/FAO data sheets on pesticides: No. 82. WHO/PCS/DS/96.82. Geneva, Switzerland: World Health Organization.

Ybarra, M., M .Magnuson, and K. Kleier. 2004. Atrazine chlorination transformation products under drinking water distribution system conditions. Washington, D.C.: U.S. EPA. Available at: www.epa.gov/ORD/NRMRL/scienceforum/ ybarra_m.pdf. Accessed: 20 December 2006. 
